\title{
Fermentation-Mediated Enhancement of Ginseng's Anti-Allergic Activity against IgE-Mediated Passive Cutaneous Anaphylaxis In Vivo and In Vitro
}

\author{
Seon-Weon Hwang ${ }^{1}$, Xiao Sun ${ }^{2}$, Jun-Hyuk Han², Tae-Yeon Kim², Sushruta Koppula ${ }^{3}$, Tae-Bong Kang ${ }^{3}$, \\ Jae-Kwan Hwang ${ }^{1,4 *}$, and Kwang-Ho Lee ${ }^{2,3 *}$ \\ ${ }^{1}$ Graduate Program in Biomaterials Science and Engineering, Yonsei University, Seoul 03722, Republic of Korea \\ ${ }^{2}$ Department of Applied Life Science, Graduate School, Konkuk University, Chungju 27478, Republic of Korea \\ ${ }^{3}$ Department of Integrated Bioscience, College of Biomedical $\mathcal{E}$ Health Science, Research Institute of Inflammatory Diseases, Konkuk \\ University, Chungju 27478, Republic of Korea \\ ${ }^{4}$ Department of Biotechnology, Yonsei University, Seoul 03722, Republic of Korea
}

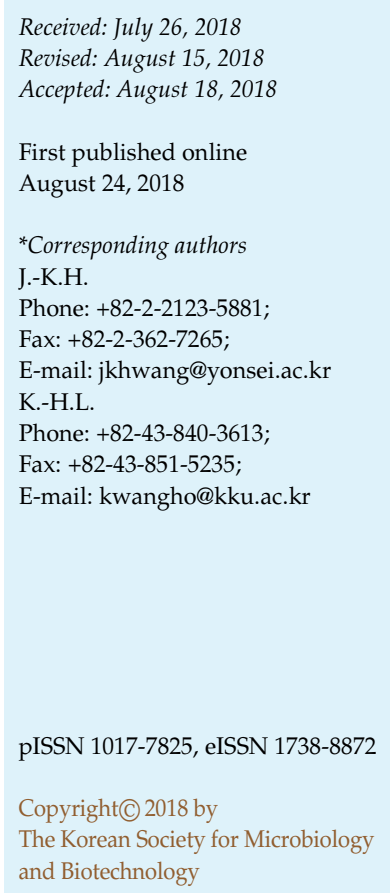

\begin{abstract}
Ginseng (the root of Panax ginseng Meyer) fermented by Lactobacillus plantarum has been found to attenuate allergic responses in in vitro and in vivo experimental models. Ginseng has been reported to also possess various biological functions including anti-inflammatory activity. The present study was aimed at comparing the anti-allergic effect of ginseng and fermented ginseng extracts on IgE-mediated passive cutaneous anaphylaxis in vitro in a murine cell line and in vivo in mice. Fermented ginseng extract (FPG) showed higher inhibitory effect against in vitro and in vivo allergic responses when compared with ginseng extract (PG). The secretion of $\beta$-hexosaminidase and interleukin (IL)-4 from the IgE-DNP-stimulated RBH-2H3 mast cells were significantly $(p<0.05)$ inhibited by FPG treatment, and this effect was concentration-dependent. Further, MKK4 activation and subsequent JNK phosphorylation were attenuated by FPG treatment. The inhibitory effect of FPG on the in vitro allergic response was verified in vivo against IgE-DNP-induced passive cutaneous anaphylaxis in a mouse model. These data indicated that the fermentation of ginseng with L. plantarum enhanced its anti-allergic effects both in vitro and in vivo. We predict that compositional changes in the ginsenosides caused by the fermentation may contribute to the change in the anti-allergic effects of ginseng. The results of our study highlight the potential of the use of FPG as a potential anti-allergic agent.
\end{abstract}

Keywords: Ginseng, fermentation, anti-allergic, anaphylaxis, Lactobacillus plantarum

\section{Introduction}

Allergies are hypersensitivity disorders mediated by immunological mechanisms that result in tissue damage and are involved in many allergic diseases such as atopic dermatitis, rhinitis, asthma, and anaphylaxis. Hence, the regulation of allergic reactions is an important and attractive research area [1, 2]. Mast cells and basophils are critical for various allergic disorders [3]. These cells express surface membrane receptors with a high affinity and specificity for IgE (FceRI) [4]. IL-4 is a key cytokine in IgE-dependent mast cell activation and allergic inflammation. Activated mast cells secrete granules containing various allergic mediators such as $\beta$-hexosaminidase, histamines, eicosanoids, and pro-inflammatory cytokines [5-7]. Mechanistically, the interaction of FceRI with antigen-bound IgE causes the activation of a signaling cascade involving phospholipase $\mathrm{C}$ and mitogen-activated protein kinases (MAPKs). The IgE 
receptor activates the JNK pathway through the MEKK2MKK4/7 cascade [8, 9]; this pathway is essential for the induced expression of some cytokine genes such as IL-4, IL-6, or TNF- $\alpha$ and is activated following antigenic mast cell activation [10, 11]. These cytokine-induced reactions then cause tissue inflammation and anaphylaxis, both of which are becoming chronic health problems worldwide [12].

Ginseng (root of Panax ginseng C.A. Meyer) from the family Araliaceae is an herbaceous plant cultivated mainly in countries in East Asia, such as Korea, China, and Japan [13]. Ginseng is considered one of the most renowned medicinal agents extensively used to treat various diseases in traditional Chinese and Oriental systems of medicine [14-16].

It is well documented that the fermentation of foods and plants enhances their biological functions [17]. Lactobacillus strains occur naturally in the human intestine, and for this reason, they are also preferentially developed for a variety of industrial food fermentations and for commercial use as probiotics [18]. Although the anti-allergic effects of ginseng and red ginseng have been previously reported [19, 20], there is no comparative study between the anti-allergic effects of ginseng and its fermented extract (FPG). In vivo, IgE-mediated passive cutaneous anaphylaxis (PCA) is a well-characterized model for studying immediate-type hypersensitivity [21]. Therefore, in the present study, we aimed to evaluate the effect of FPG on allergic reactions in RBL-2H3 cells in vitro as well as on the prevention of IgEinduced PCA in vivo and compared it with that of ginseng extract (PG). Our results highlight the potential for use of FPG as an anti-allergic agent.

\section{Materials and Methods}

\section{Reagents and Antibodies}

Minimum essential medium (MEM), fetal bovine serum (FBS), opti-MEM, and penicillin-streptomycin were purchased from Gibco (USA). De Man, Rogosa and Sharpe (MRS) media, Rat IL-4 ELISA kit, and TMB substrate reagent were purchased from BD Biosciences (USA). Lactate dehydrogenase (LDH) assay kit (CytoTox 96) was purchased from Promega (USA). Antibodies against MAPKs and p-MKK4 were purchased from Cell Signaling Technology Inc. (USA). $\beta$-actin antibody was purchased from Santa Cruz Biotechnology (USA). MTT (3-(4,5-dimethylthiazol-2yl)-2,5-diphenyltetrazolium bromide), Evans blue, formamide, anti-dinitrophenyl (DNP)-IgE, dinitrophenyl-conjugated human serum albumin (DNP-HSA), 4-nitrophenyl N-acetyl- $\beta$-Dglucosaminide, JNK inhibitor SP600125, and all other chemicals were purchased from Sigma Aldrich Co. (USA).

\section{Preparation of Ginseng}

Panax ginseng was cultivated at Jiri Mountain in South Gyeongsang Province, Korea. The roots of $P$. ginseng were collected from 2-year-old plants, and then, washed and dried. The dried roots were crushed and extracted with $70 \%$ ethanol for $4 \mathrm{~h}$ at $65^{\circ} \mathrm{C}$. The obtained extract was then evaporated under reduced pressure at $50^{\circ} \mathrm{C}$ (BUCHI Rotavapor R-210) to remove ethanol, resulting in the final $P$. ginseng extract (PG) with a concentration of $7 \%-9 \%(w / w)$, which was used for fermentation.

\section{Fermentation of Ginseng}

The protocol for the fermentation of ginseng was as reported previously [22] with slight modifications. L. plantarum (HSW-01) was cultured in MRS broth at $30^{\circ} \mathrm{C}$, and the ginseng extract was inoculated with L. plantarum (1 portion of extract: 10 portions of L. plantarum cultured media, $\mathrm{v} / \mathrm{v}$ ) and incubated for 100 days at $4^{\circ} \mathrm{C}$. After 100 days, the fermented ginseng extract was filtered (Advantec filter paper, $5 \mu \mathrm{m}$ ) and concentrated to achieve 10 brix in a rotary evaporator at $50^{\circ} \mathrm{C}$. The concentrates were further mixed with $95 \%$ ethanol to elute saponins by agitating for $2 \mathrm{~h}$ at $40^{\circ} \mathrm{C}$. The eluates were then filtered using a filter paper, concentrated in a rotary evaporator, and dissolved in $40 \%$ butylene glycol solution $(5 \mathrm{x} ; \mathrm{v} / \mathrm{v})$ for $1 \mathrm{~h}$. Next, butylene glycol was removed under reduced pressure in a rotary evaporator, and the concentrates were finally mixed with $95 \%$ ethanol and agitated. The ethanol was then removed using a rotary evaporator. The final yield of fermented ginseng extract (FPG) was approximately $5 \%$ of the starting dried ginseng material. The extract from the incubation of L. plantarum in MRS broth without ginseng extract under the same conditions (BL) was used as the control.

\section{Cell Culture and Animal Treatment}

RBL-2H3 cells were obtained from the American Type Culture Collection (ATCC, USA) and cultured in MEM with 15\% FBS, $100 \mathrm{U} / \mathrm{ml}$ penicillin, and $100 \mu \mathrm{g} / \mathrm{ml}$ streptomycin at $37^{\circ} \mathrm{C}$ in a humidified incubator $\left(5 \% \mathrm{CO}_{2}, 95 \%\right.$ air). For the in vivo studies, female BALB/c mice ( 6 weeks old) were obtained from ORIENT Co., Korea and housed for 1 week on a 12-h light-dark cycle at $24 \pm 1^{\circ} \mathrm{C}$ with access to food and water ad libitum. All experiments were performed in accordance with the institutional guidelines and were approved by the Institutional Animal Care and Use Committee (IACUC) at Konkuk University, Korea (Permit number KU18001).

\section{Degranulation Assay of $\beta$-Hexosaminidase}

Degranulation from the RBL-2H3 cells was evaluated by measuring the activity of $\beta$-hexosaminidase enzyme secreted in the extracellular medium. Cells were pre-cultured in 24-well plates $\left(1.5 \times 10^{5}\right.$ cells/well $)$ overnight and then sensitized with anti-DNP IgE $(110 \mathrm{ng} / \mathrm{ml})$ antibodies for $2 \mathrm{~h}$. After sensitization, the medium was replaced with opti-MEM, and cells were incubated for $1 \mathrm{~h}$ with or without BL, FPG, PG, or SP600125. Subsequently, surface IgE was cross-linked with DNP-HSA 
( $25 \mathrm{ng} / \mathrm{ml}$ ) for $15 \mathrm{~min}$.

After sensitizing the cells, the culture supernatant $(30 \mu \mathrm{l})$ was transferred to $96-$ well plates and incubated with $30 \mu \mathrm{l}$ of substrate (1 mM p-nitrophenyl-N-acetyl- $\beta$-D-glucosaminide in citrate $0.05 \mathrm{M}$, $\mathrm{pH} 4.5$ ) for $60 \mathrm{~min}$ at $37^{\circ} \mathrm{C}$. The cells were then lysed with $0.1 \%$ Triton X-100 before removing the supernatant to measure the total $\beta$-hexosaminidase activity. The reaction was stopped by adding $200 \mu \mathrm{l}$ of $0.1 \mathrm{M} \mathrm{Na}_{2} \mathrm{CO}_{3}-\mathrm{NaHCO}_{3}$ buffer at $\mathrm{pH} 10$. The color generated was measured at $405 \mathrm{~nm}$ using a spectrophotometric microplate reader (Molecular Devices Corp., USA). The percentage of specific $\beta$-hexosaminidase release was calculated as follows: percentage release $=100 \times$ supernatant activity $/$ (supernatant activity + cell lysate activity) [23]).

\section{Assessment of Cytotoxicity Via Cell Viability (MTT) and Cell Cytotoxicity (LDH) Assays}

The protocol for MTT and LDH assay was followed as described previously [24]. Briefly, cells were cultured in 96-well plates $(1 \times$ $10^{4}$ cells/well) overnight and then treated with diluted BL, FPG, or PG and incubated for $24 \mathrm{~h}$. Cell cytotoxicity was measured with a LDH assay method using the cytotox $96 \mathrm{kit}$ (G1780) according to the manufacturer's instructions. Percent cytotoxicity $=100 \times$ (leaked LDH OD value of experimental group - LDH OD value of non-treated cells group)/(LDH OD value of positive control group - LDH OD value of non-treated cells group). For MTT assay, the medium was discarded completely and $100 \mu \mathrm{l}$ of MEM medium containing MTT $(500 \mu \mathrm{g} / \mathrm{ml})$ was added to each well, followed by incubation for $2 \mathrm{~h}$ at $37^{\circ} \mathrm{C}$. After incubation, medium was discarded and DMSO was added to each well for the solubilization of formazan. Optical density was measured at $550 \mathrm{~nm}$, and value was determined in comparison to control cells. Percent viability $=100 \times$ experimental cells OD/Non-treated cells OD.

Enzyme-Linked Immunosorbent Assay (ELISA) for IL-4 Secretion

Supernatants of the cultured RBL-2H3 cells were collected $6 \mathrm{~h}$ after DNP-HSA stimulation, and the concentration of IL-4 was measured with a commercial sandwich ELISA method using the BD OptEIATM Set (555198) according to the manufacturer's instructions. The color generated was measured at $450 \mathrm{~nm}$ using a spectrophotometric microplate reader.

\section{SDS-PAGE and Immunoblotting}

The conditions used for the immunoblot analysis were as described previously [24]. The membrane was developed for visualization using an ECL detection kit developed by Chemiluminescence imaging systems (Davinch-Chemi; DavinchK, Korea).

\section{IgE-Mediated PCA in Mice}

$\mathrm{BALB} / \mathrm{c}$ mice were passively sensitized with IgE by intradermal injection in the ears, using $500 \mathrm{ng}$ monoclonal mouse dinitrophenolspecific (anti-DNP) IgE in $20 \mu \mathrm{l}$ of PBS. After $24 \mathrm{~h}$, the mice were intravenously injected with $100 \mu \mathrm{g}$ of DNP-HSA in $200 \mu \mathrm{l}$ of PBS containing $2 \%$ Evans blue. FPG (25 or $50 \mathrm{mg} / \mathrm{kg}$ ) and PG $(100 \mathrm{mg} / \mathrm{kg})$ were administered intraperitoneally $1 \mathrm{~h}$ before DNPHSA injection. The mice were sacrificed after $20 \mathrm{~min}$, and the Evans blue was extracted by incubating ear samples of equal size in $200 \mu \mathrm{l}$ of formamide for $12 \mathrm{~h}$ at $64^{\circ} \mathrm{C}$. The optical absorbance of the Evans blue was measured at $620 \mathrm{~nm}$ using a spectrophotometric microplate reader.

\section{LC-MS/MS Analysis}

A Waters UPLC system and tandem quadrupole mass spectrometer system (USA) were used for LC-MS/MS analysis. Chromatographic separation was performed using a UPLC BEH C18 column $\left(2.1 \times 100 \mathrm{~mm}^{2}\right)$ with $1.7 \mu \mathrm{M}$ packing. The gradient and running time were as shown in Table 1 . The electrospray ionization interface (ESI) was operated in both negative modes (desolvation temperature $300^{\circ} \mathrm{C}$, source temperature $120^{\circ} \mathrm{C}$, desolvation gas flow $600 \mathrm{l} / \mathrm{h}$, cone gas flow $50 \mathrm{l} / \mathrm{h}$ ). The mass spectrometer was operated in MS-MS modes with collision cell gas pressure (argon) set at $1.2 \times 10^{-3} \mathrm{~T}$.

\section{Statistical Analyses}

Data are represented as mean \pm standard error of mean (S.E.M.). The statistical analysis of the results was performed by one-way ANOVA, followed by Tukey's multiple comparison tests. Data were analyzed using statistical Prism Software (GraphPad Software Inc., USA) and values of $p<0.05$ were considered statistically significant.

\section{Results}

FPG Inhibits FceRI-Mediated Allergic Reactions In Vitro

RBL-2H3 cells were used as the in vitro model to evaluate the anti-allergic effect of FPG and PG. The cytotoxicity of BL, FPG, and PG on RBL-2H3 cells was examined using the

Table 1. Column gradients and sample running time ${ }^{\dagger}$.

\begin{tabular}{cccc}
\hline $\begin{array}{c}\text { Time } \\
(\mathrm{min})\end{array}$ & $\begin{array}{c}\text { Flow } \\
(\mathrm{ml} / \mathrm{min})\end{array}$ & $\begin{array}{c}\% \text { A } \\
(0.1 \% \text { Formic acid })\end{array}$ & $\begin{array}{c}\% \text { B } \\
\text { (Acetonitrile })\end{array}$ \\
\hline Initial & 0.3 & 80 & 20 \\
0.10 & 0.3 & 80 & 20 \\
2.00 & 0.3 & 68 & 32 \\
7.00 & 0.3 & 67 & 33 \\
20.00 & 0.3 & 48 & 52 \\
23.00 & 0.3 & 47 & 53 \\
26.00 & 0.3 & 20 & 80 \\
26.90 & 0.3 & 0 & 100 \\
27.00 & 0.3 & 80 & 20 \\
30.00 & 0.3 & 80 & 20 \\
\hline
\end{tabular}


A

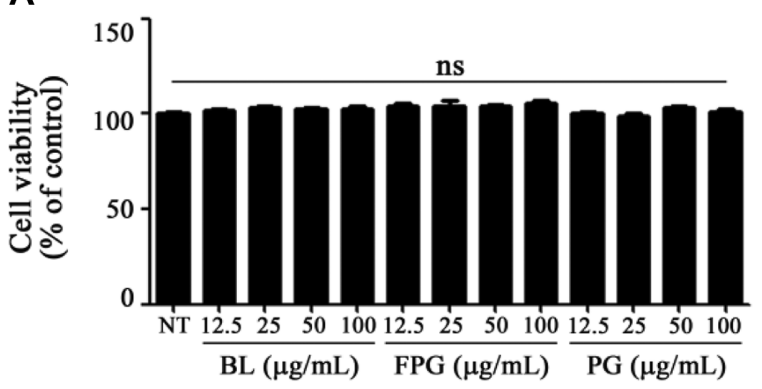

C
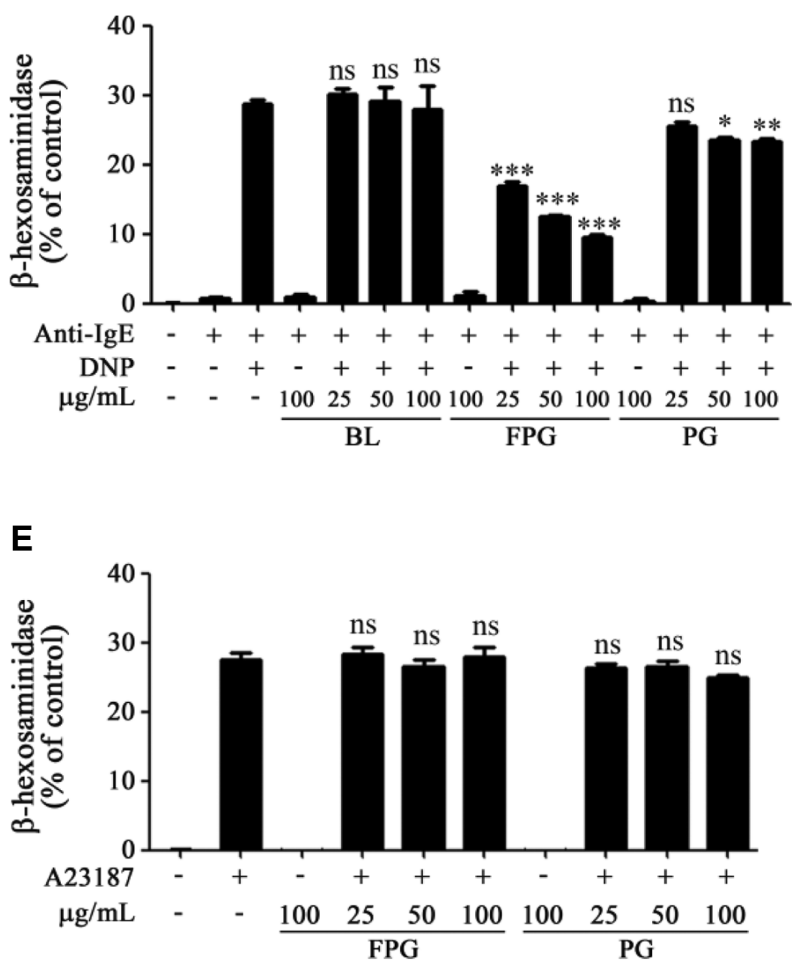

B

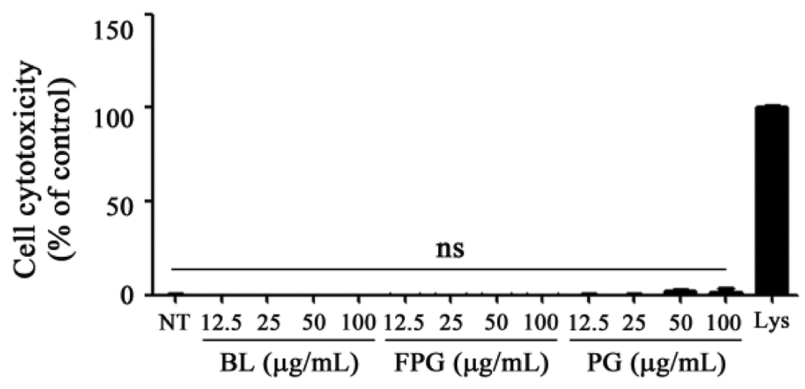

D

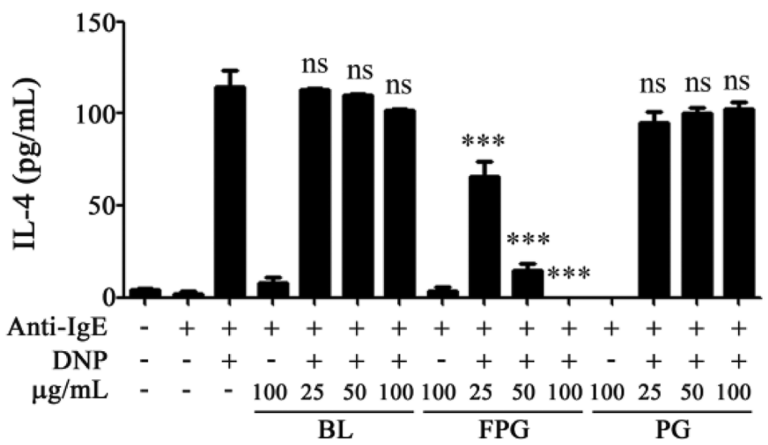

Fig. 1. Inhibitory effects of FPG on allergic responses in vitro and in vivo.

RBL-2H3 cells were treated with various concentrations of BL, FPG, and PG for $24 \mathrm{~h}$. Cell viability was measured using the MTT assay (A), and cytotoxicity was measured using the LDH assay (B). Non-treated cells (NT) were used as the negative control, and whole cell lysate (Lys) was used as the positive control. (C) RBL-2H3 cells were incubated with anti-DNP IgE $(110 \mathrm{ng} / \mathrm{ml})$ and then treated with various concentrations of BL, FPG, or PG; subsequently, surface IgE was cross-linked with or without DNP-HSA $(25 \mathrm{ng} / \mathrm{ml})$ for $15 \mathrm{~min}$. The percentage of specific $\beta$ hexosaminidase release was determined as described in the methods. (D) FcERI-induced RBL-2H3 cells were stimulated with or without DNPHSA for $6 \mathrm{~h}$. IL-4 production was determined using ELISA. (E) RBL-2H3 cells were treated with various concentrations of FPG and PG and then stimulated with or without A23187. Data represent the mean \pm SEM of three independent experiments; ${ }^{*} p<0.05,{ }^{* *} p<0.01,{ }^{* * *} p<0.001$, ns: nonsignificant.

MTT and LDH assays. As shown in Figs. 1A and 1B, treatment with BL, FPG, and PG at concentrations up to $100 \mu \mathrm{g} / \mathrm{ml}$ did not result in cytotoxicity. Therefore, we chose $100 \mu \mathrm{g} / \mathrm{ml}$ as the maximum concentration for subsequent experiments in RBL-2H3 cells.

Mast cells mediate the early phase of type I hypersensitivity reactions by releasing granule contents and cytokines after cross-linking with FceRI [25]. Therefore, we measure the inhibitory effects of FPG and PG on FceRI-mediated degranulation in RBL-2H3 cells with the release of $\beta$ hexosaminidase as the degranulation biomarker [26]. As shown in Fig. 1C, the IgE-DNP-induced $\beta$-hexosaminidase release was significantly inhibited by FPG treatment, and this effect was concentration dependent. However, BL did 
not show a significant inhibitory effect on $\beta$-hexosaminidase release. PG showed marginal inhibition in $\beta$-hexosaminidase release; however, the decrease in $\beta$-hexosaminidase release with PG was not as marked as that with FPG.

Further, IL-4 plays an important role in facilitating mast cell activation as well as in inducing the secretion of other Th2 type cytokines [27, 28]. In this study, IgE-sensitized RBL-2H3 cells were treated with BL, FPG, or PG and challenged with DNP-HSA. The results showed that FPG treatment, but not BL or PG treatment, significantly ( $p<$ 0.05 ) decreased the secretion of IL-4, and this effect was concentration dependent (Fig. 1D). Since BL did not show any significant inhibitory effect on allergic responses in vitro, we excluded them in subsequent experiments and only examined the inhibitory activities of FPG and PG on allergic responses in vitro and in vivo.

The calcium ionophore A23187 can increase intracellular concentrations of $\mathrm{Ca}^{2+}$; this influx of $\mathrm{Ca}^{2+}$ subsequently triggers the degranulation of mast cells by bypassing receptor activation [29]. Therefore, to explore the effects of FPG/PG on receptor bypassing degranulation from RBL$2 \mathrm{H} 3$ cells, we pre-treated the cells with FPG or PG and subsequently induced them with A23187. We found that neither FPG nor PG had any effect on the release of $\beta$-hexosaminidase (Fig. 1E), indicating that FPG effectively attenuates FceRI-mediated hypersensitivity reaction in mast cells.

Together these results from our in vitro experiments indicated that the fermentation of ginseng with L. plantarum enhances its anti-allergic properties.

\section{FPG Attenuates PCA In Vivo}

To verify the inhibitory effects of FPG on allergic responses in vivo, we used a mouse model of IgE-DNP-
A

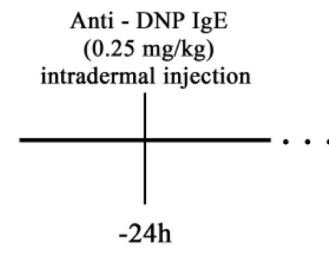

B

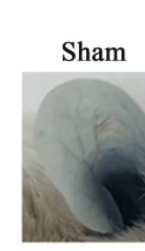

\section{FPG, PG, DEX} intraperitoneal injection

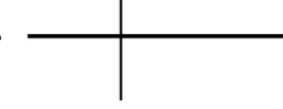

$-1 \mathrm{~h}$

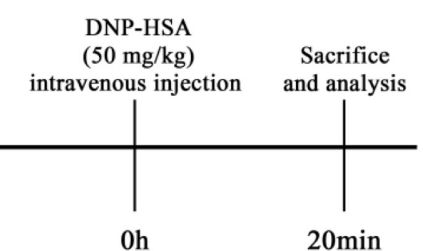

Oh

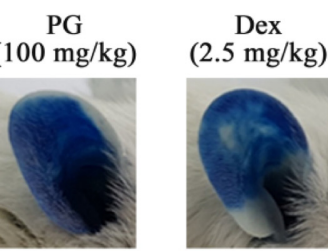

C
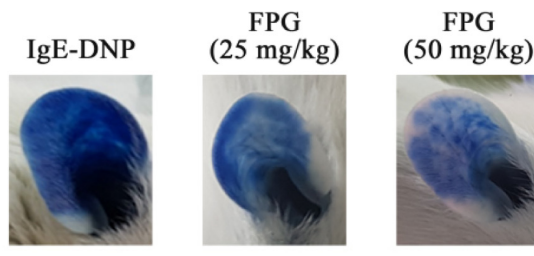

$*$

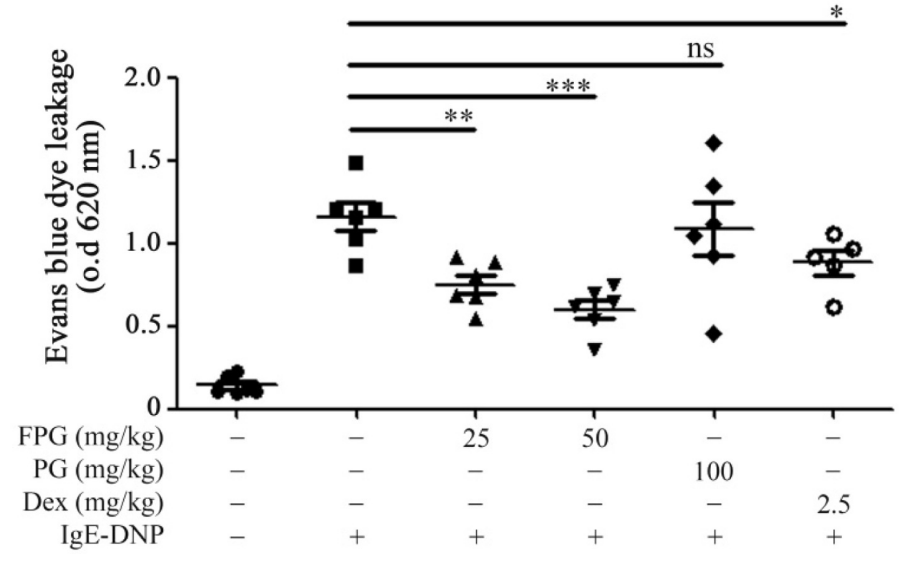

Fig. 2. In vivo efficacy of PG and FPG on PCA.

(A) The experimental scheme for PCA and treatment with FPG $(25,50 \mathrm{mg} / \mathrm{kg})$, PG $(50 \mathrm{mg} / \mathrm{kg})$, or DEX $(2.5 \mathrm{mg} / \mathrm{kg})(n=6)$. (B) Upon DNP-HSA challenge, vascular leakage was assayed by measuring Evans blue extravasation into ear tissues. (C) Ear samples of equal size were excised 20 min after the intravenous challenge with antigen and Evans blue, and subsequently extracted in formamide. Each point showed the mean optical density at $620 \mathrm{~nm}$. Data represent the mean \pm SEM of three independent experiments; ${ }^{*} p<0.05,{ }^{* *} p<0.01,{ }^{* * *} p<0.001$, ns: non-significant. 
induced PCA (Fig. 2A). The ears of BALB/c mouse were injected intradermally with monoclonal DNP-specific IgE antibody and FPG or PG was subsequently injected intraperitoneally. As shown in Figs. 2B and 2C, the DNPantigen induced strong PCA concomitant with rapidly occurring capillary dilatation and leakage of Evans blue dye into the reaction site of the mouse ears. Leakage of the injected Evans blue dye was significantly and dosedependently suppressed by pre-treatment with either FPG or dexamethasone, a known anti-allergic positive control [6]. PG, even with at a higher concentration $(100 \mathrm{mg} / \mathrm{kg})$ than that used for FPG $(50 \mathrm{mg} / \mathrm{kg}$ ) could not attenuate the anaphylactic responses.

\section{FPG Attenuates FceRI-Mediated JNK Activation}

Fc\&RI aggregation activates diacylglycerol (DAG), inducing the activation of protein kinase $\mathrm{C}$ (PKC) and the downstream MAPK pathway, including the phosphorylation of JNK, p38, and ERK; these in turn lead to the transcription of cytokine genes $[9,30]$. Therefore, we investigated the potential involvement of MAPKs in FPG-induced regulation to elucidate the mechanism underlying the role of FPG in the FceRI-triggered signaling pathway, which is stimulated by the binding of FceRI to IgE cross-linked to DNP. As shown in Fig. 3A, FPG decreased IgE-DNP-induced phosphorylation of JNK, but not that of ERK or p38. Mitogen-activated protein kinase kinase 4 (MKK4), a member of the MAP kinase kinase family, directly phosphorylates and activates the JNK pathway [31]. We therefore aimed to determine the role of FPG in the phosphorylation of MKK4 at 7 and 15 min after the cross-linking of FceRI with IgE-DNP. FPG also decreased the IgE-DNP-induced phosphorylation of MKK4 in a concentration-dependent manner (Fig. 3B). Next, to elucidate the role of FPG in the correlation between MKK-mediated JNK activation and degranulation, RBL-2H3 cells were pre-incubated with SP600125, a JNK inhibitor, and then subjected to IgE-DNP treatment. As shown in Fig. 3C, both SP600125 and FPG dose-dependently and significantly $(p<0.05)$ inhibited the release of $\beta$-hexosaminidase from RBL-2H3 cells, indicating that the MKK-JNK pathway is at least partly involved in the FPG-mediated regulation of degranulation from RBL-2H3 cells.

\section{Analysis of Ginsenosides in FPG and PG}

Extensive studies on the role of ginsenosides have led to a partial understanding of the physiological functions of ginseng. In our experiments, to analyze the prominent antiallergic function of FPG, we analyzed 30 kinds of ginsenosides from PG and FPG. Table 2A shows the ginsenosides that exhibited similar levels in FPG and PG or those whose levels were decreased due to fermentation. The levels of many other ginsenosides were also increased upon fermentation of ginseng (Fig. 2B).

\section{Discussion}

In the present study, we found that the fermentation of $P$. ginseng extract enhanced its anti-allergic effects in vitro and in vivo. We also found that the improvement in the anti-allergic effects upon fermentation was due to the attenuation of the FceRI-induced phosphorylation of the MKK4-JNK pathway, which resulted in reduced secretion of FceRI-mediated $\beta$-hexosaminidase and IL-4 in mast cells. Further, our study revealed that the levels of several constituent ginsenosides were altered by the fermentation of ginseng. FPG significantly and more strongly inhibited IgE-induced PCA compared with PG, suggesting that the increase in the anti-allergic effect of ginseng upon fermentation may be due to the altered active constituents. Our experiments also showed that the levels of some of the ginsenosides were increased, while those of some others were decreased upon fermentation.

In a previous study, the ginsenosides $\mathrm{Rb} 1, \mathrm{Rd}, \mathrm{F} 2$, and compound $\mathrm{K}(\mathrm{C}-\mathrm{K})$ were reported to induce $\beta$-hexosaminidase release from RBL-2H3 cells [3]. In contrast, the ginsenosides $\mathrm{Rh} 1, \mathrm{Rh} 2, \mathrm{Rg} 1$, and Rg3 have been reported to inhibit allergic responses [32-35]. Furthermore, Rg3 has been reported to reduce inflammatory responses in human asthmatic airway epithelial cells and tissues [35]. Consistent with these reports, we found that FPG showed lower levels of $\mathrm{Rb1}, \mathrm{Rb} 2$, and $\mathrm{C}-\mathrm{K}$ and had enhanced anti-allergic effect compared to PG and that the levels of Rh1, Rh2, and Rg3 were higher in FPG than in PG. Although the levels of Rg1 were decreased and those of $\mathrm{Rd}$ and F2 were increased in FPG, which is contrary to previous reports [3, 36], FPG showed more intense anti-allergic activity. One limitation of our study is that we were unable to identify the ginsenosides actively involved in the improvements in the anti-allergic effect of PG upon fermentation. Future studies are needed to determine whether the anti-allergic effects of FPG are controlled by a single ginsenoside or if these effects are a coordinated action of multiple ginsenosides.

However, we could not identify the exact active constituent present in ginsenosides that helped in the enhanced antiallergic effect of PG upon fermentation. Further studies are needed to determine whether the anti-allergic effects of 
A
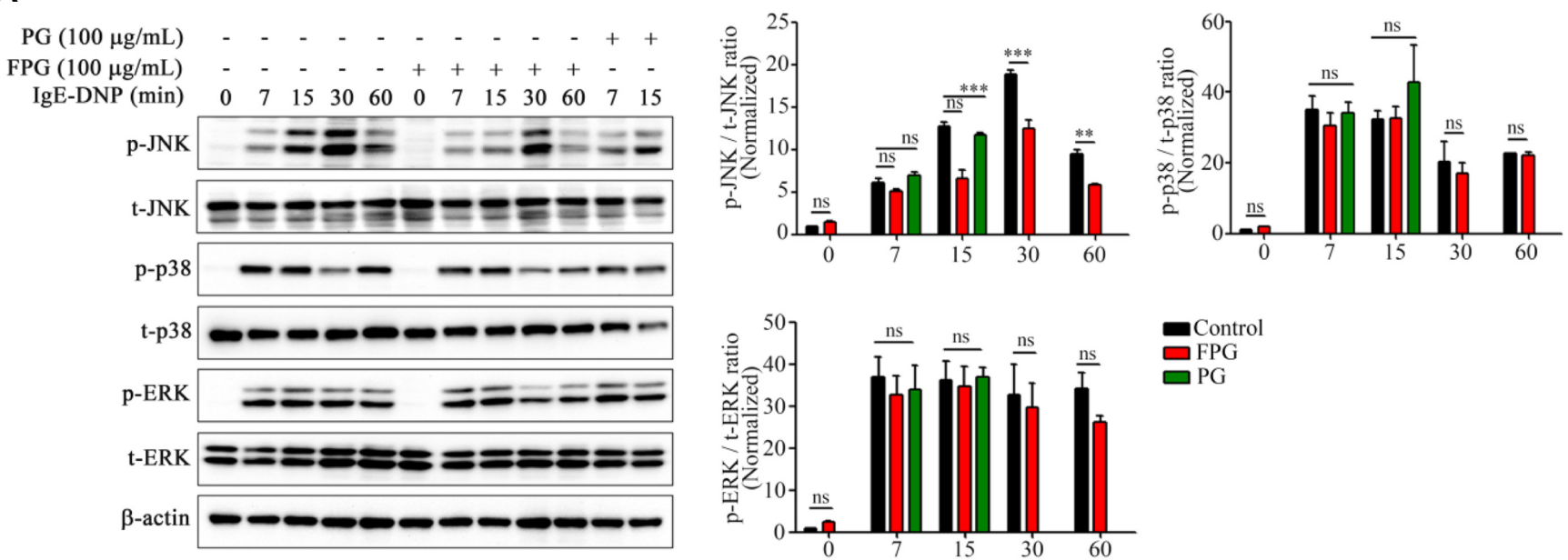

B

$\begin{array}{llllllllllllllll}\text { IgE-DNP (min) } & - & - & - & 7 & 7 & 7 & 7 & 7 & 7 & 15 & 15 & 15 & 15 & 15\end{array}$ $\operatorname{SP} 600125(5 \mu \mathrm{M}) \quad-\quad-\quad-\quad-\quad-\quad-\quad+\quad-\quad-\quad-\quad-$

$\mathrm{PG}(\mu \mathrm{g} / \mathrm{mL})-\quad-100-\quad-\quad-100-\quad-\quad-100$

FPG $(\mu \mathrm{g} / \mathrm{mL}) \quad-100 \quad-2550100-\quad-\quad 2550100 \quad-$
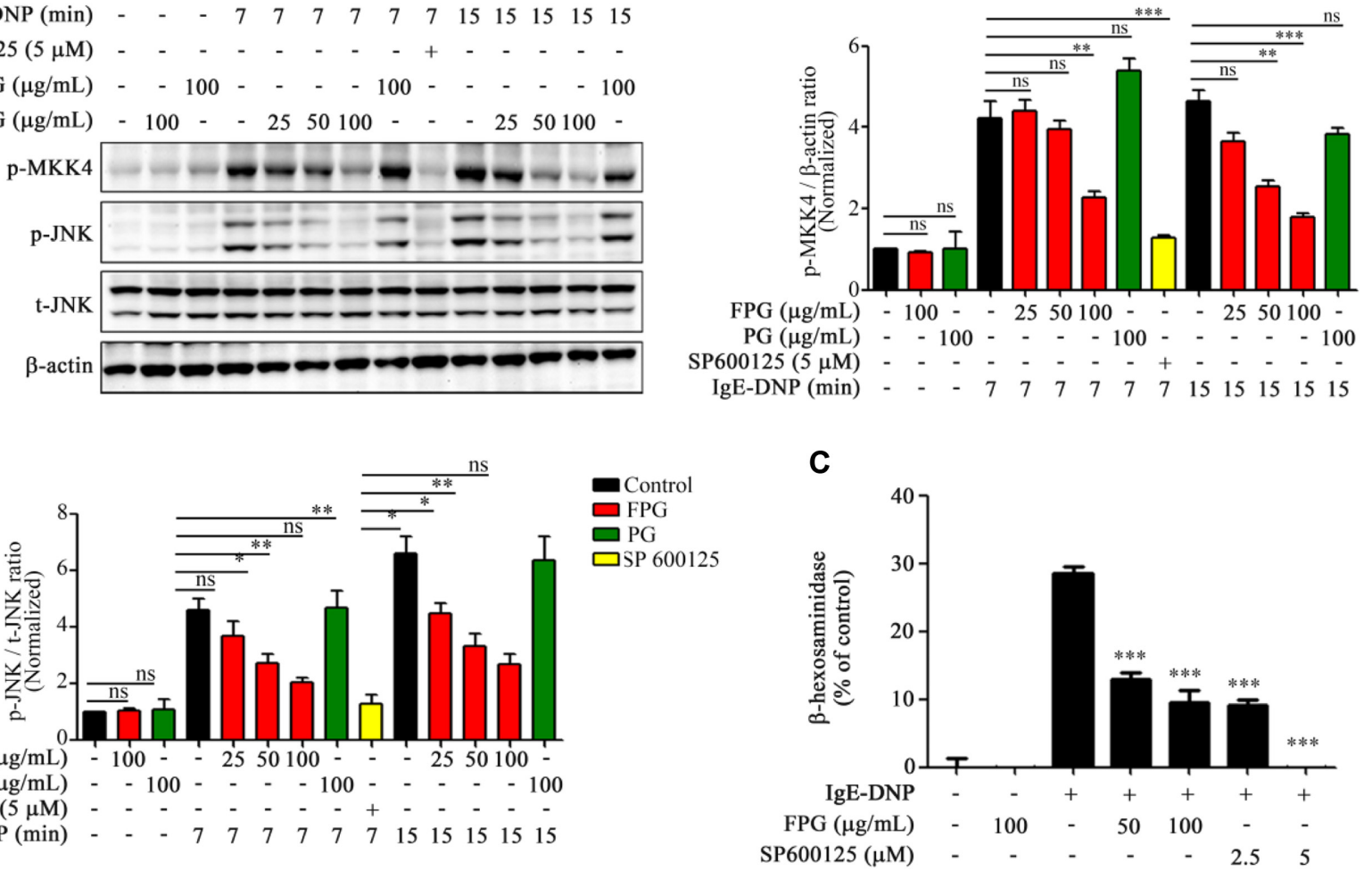

Fig. 3. Involvement of FceRI-mediated MKK4-JNK pathway in the anti-allergic effect of FPG.

(A, B) RBL-2H3 cells were incubated with anti-DNP IgE $(110 \mathrm{ng} / \mathrm{ml})$ for $2 \mathrm{~h}$, treated with the indicated amount of FPG, PG, or SP600125 for $1 \mathrm{~h}$, and then cross-linked with or without DNP-HSA for the indicated times. Cell lysates were analyzed by western blot analyses using specific antibodies. $\beta$-actin was used as the internal control. The statistical band intensities are indicated with the histogram. (C) RBL-2H3 cells were incubated with anti-DNP IgE $(110 \mathrm{ng} / \mathrm{ml})$, treated with various concentrations of FPG or SP600125, and subsequently stimulated with or without DNP-HSA $(25 \mathrm{ng} / \mathrm{ml})$ for $15 \mathrm{~min}$. The percentage of specific $\beta$-hexosaminidase release was determined as described in the methods. The bar graphs present the mean values \pm SEM of three independent experiments; ${ }^{*} p<0.05,{ }^{* *} p<0.01$, or ${ }^{* * *} p<0.001$, ns: non-significant.

FPG are controlled by a single ginsenoside constituent or a combined effect of all ginsenosides present in FPG.

In conclusion, we observed that the fermentation of ginseng is a beneficial technique to increase the anti-allergic effect of ginseng. This study provides scientific evidence for the therapeutic efficacy of FPG in the prevention of allergic 
Table 2. Altered constituents of ginsenosides in FPG and PG.

\begin{tabular}{cccc}
\hline A & & & \\
\hline Ginsenosides $(\mathrm{mg} / \mathrm{kg})$ & PG & FPG & PG - FPG (ई) \\
\hline Rb1 & 4415.65 & 246.7 & 4168.95 \\
Re & 2699.66 & 2465.4 & 234.26 \\
Rg1 & 2071.3 & 793 & 1278.3 \\
Rc & 1921.93 & 494.6 & 1427.33 \\
Rb2 & 1598.29 & 788.9 & 809.38 \\
Rf & 945.63 & 34.2 & 911.43 \\
Ro & 483.97 & 10.47 & 473.5 \\
C-K & 39.83 & 8.45 & 31.38 \\
\hline
\end{tabular}

B

\begin{tabular}{|c|c|c|c|}
\hline Ginsenosides (mg/kg) & PG & FPG & FPG - PG (仓) \\
\hline $\mathrm{Rd}$ & 1156.94 & 2000.8 & 843.86 \\
\hline $\mathrm{Rb} 3$ & 180.64 & 1115.4 & 934.76 \\
\hline $\operatorname{Rg} 2(S)$ & 180.24 & 452.6 & 272.36 \\
\hline $\mathrm{F} 2$ & 13.84 & 436.1 & 422.26 \\
\hline $\mathrm{F} 1$ & 10.66 & 383.3 & 372.64 \\
\hline $\mathrm{C}-\mathrm{O}$ & 4.78 & 312.8 & 308.02 \\
\hline $\operatorname{Rg} 6$ & 3.88 & 285.4 & 281.52 \\
\hline $\mathrm{C}-\mathrm{Mx} 1$ & - & 276 & 276 \\
\hline Rg2(R) & 3.49 & 261.8 & 258.31 \\
\hline Rh1(S) & 37.04 & 241.83 & 204.79 \\
\hline $\mathrm{Rh} 4$ & 5.88 & 208.33 & 202.45 \\
\hline $\operatorname{Rg} 3(S)$ & 20.51 & 200.1 & 179.59 \\
\hline C-Mc1 & 10.26 & 195.8 & 185.54 \\
\hline $\operatorname{Rg} 4$ & 3.58 & 142.62 & 139.04 \\
\hline $\operatorname{Rg} 5$ & 3.98 & 141.7 & 137.72 \\
\hline $\operatorname{Rg} 3(\mathrm{R})$ & 0.1 & 107.78 & 107.68 \\
\hline Rk1 & 30.87 & 87.85 & 56.98 \\
\hline $\operatorname{Rh} 1(\mathrm{R})$ & 14.44 & 82.07 & 67.63 \\
\hline PPTol & 0.6 & 73.2 & 72.6 \\
\hline Gyp17 & 23.5 & 68.5 & 45 \\
\hline Rk3 & - & 40.9 & 40.9 \\
\hline $\operatorname{Rh} 2(S)$ & - & 25.72 & 25.72 \\
\hline $\mathrm{Rh} 2(\mathrm{R})$ & - & 15.74 & 15.74 \\
\hline Rh3 & - & 13.81 & 13.81 \\
\hline Rk2 & - & 11.22 & 11.22 \\
\hline PPDol & 3.88 & 8.06 & 4.18 \\
\hline$C-Y$ & 2.79 & 5.61 & 2.82 \\
\hline C-Mx & 0.32 & 5.2 & 4.88 \\
\hline C-Mc & - & 3.94 & 3.94 \\
\hline
\end{tabular}

Representative chromatograms from LC-MS/MS are shown. (A) Ginsenosides with reduced levels (囚) in FPG compared with PG. (B) Ginsenosides with increased levels $(\widehat{\imath})$ in FPG compared with PG. Data represent the mean \pm SEM of three independent experiments; ${ }^{* *} p<0.001$, ns: non-significant. reactions and highlights the potential of the development of FPG as a promising agent in the treatment of anaphylaxis, pruritus, and other inflammatory diseases.

\section{Acknowledgements}

This work was supported by Business for Cooperative R\&D between Korea Association of Industry, Academy and Research Institute funded by the Ministry of SMEs and Startups in 2017 [Grant No.: C0512755].

\section{Conflict of Interest}

The authors have no financial conflicts of interest to declare.

\section{References}

1. Jeon J, Kim Y, Kim H, Kang JS. Lee WJ. 2015. Antiinflammatory effect of alloferon on ovalbumin-induced asthma. Immune Netw. 15: 304-312.

2. Han SY, Bae JY, Park SH, Kim YH, Park JH, Kang YH. 2013. Resveratrol inhibits IgE-mediated basophilic mast cell degranulation and passive cutaneous anaphylaxis in mice. $J$. Nutr. 143: 632-639.

3. Wang L, Zhang F, Cao Z, Xiao Y, Li S, Yu B, Qi J. 2017. Ginsenoside F2 induces the release of mediators associated with Anaphylactoid reactions. Fitoterapia 121: 223-228.

4. Lee JH, Kim JW, Kim DJ, Kim HS, Park HJ, Park DK, et al. 2011. The Src family kinase Fgr is critical for activation of mast cells and IgE-mediated anaphylaxis in mice. J. Immunol. 187: 1807-1815.

5. Lim SJ, Kim M, Randy A, Nho CW. 2015. Inhibitory effect of the branches of Hovenia dulcis Thunb. and its constituent pinosylvin on the activities of IgE-mediated mast cells and passive cutaneous anaphylaxis in mice. Food Funct. 6: 13611370.

6. Je IG, Kim DS, Kim SW, Lee S, Lee HS, Park EK, et al. 2015. Tyrosol suppresses allergic inflammation by inhibiting the activation of phosphoinositide 3-kinase in mast cells. PLoS One 10: $\mathrm{e} 0129829$.

7. Park KI, Kim DG, Yoo JM, Ma JY. 2016. The Herbal Medicine KIOM-MA128 inhibits the antigen/ige-mediated allergic response in vitro and in vivo. Molecules 21: E1015.

8. Turner H, Kinet JP. 1999. Signalling through the highaffinity IgE receptor FceRI. Nature 402: B 24-30.

9. Kawakami Y, Hartman SE, Holland PM, Cooper JA, Kawakami T. 1998. Multiple signaling pathways for the activation of JNK in mast cells: involvement of Bruton's tyrosine kinase, protein kinase $\mathrm{C}$, and JNK kinases, SEK1 and MKK7. J. Immunol. 161: 1795-1802.

10. Song JS, Haleem-Smith H, Arudchandran R, Gomez J, Scott 
PM, Mill JF, et al. 1999. Tyrosine phosphorylation of Vav stimulates IL-6 production in mast cells by a Rac/c-Jun Nterminal kinase-dependent pathway. J. Immunol. 163: 802-810.

11. Garrington TP, Ishizuka T, Papst PJ, Chayama K, Webb S, Yujiri $\mathrm{T}$, et al. 2000. MEKK2 gene disruption causes loss of cytokine production in response to $\operatorname{IgE}$ and $\mathrm{c}-\mathrm{Kit}$ ligand stimulation of ES cell-derived mast cells. EMBO J. 19: 53875395.

12. Trinh H, Ba EA, Hyun YJ, Jang YA, Yun HK, Hong SS, Kim DH. 2010. Anti-allergic effects of fermented Ixeris sonchifolia and its constituent in mice. J. Microbiol Biotechnol. 20: 217-223.

13. Baeg IH, So SH. 2013. The world ginseng market and the ginseng (Korea). J. Ginseng Res. 37: 1-7.

14. Jiao L, Li B, Wang M, Liu Z, Zhang X, Liu S. 2014. Antioxidant activities of the oligosaccharides from the roots, flowers and leaves of Panax ginseng C.A. Meyer. Carbohydr. Polym. 106: 293-298.

15. Kim DY, Ro JY, Lee CH. 2015. 20 (S)-Protopanaxatriol inhibits release of inflammatory mediators in immunoglobulin Emediated mast cell activation. J. Ginseng Res. 39: 189-198.

16. Lim CY, Moon JM, Kim BY, Lim SH, Lee GS, Yu HS, et al. 2015. Comparative study of Korean white ginseng and Korean red ginseng on efficacies of OVA-induced asthma model in mice. J. Ginseng Res. 39: 38-45.

17. Liu S, Han Ye, Zhou Z. 2011. Lactic acid bacteria in traditional fermented Chinese foods. Food Res. Int. 44: 643-651.

18. Vizoso Pinto MG, Franz CM, Schillinger U, Holzapfel WH. 2006. Lactobacillus spp. with in vitro probiotic properties from human faeces and traditional fermented products. Int. J. Food Microbiol. 109: 205-214.

19. Jung JH, Kang IG, Kim DY, Hwang YJ, Kim ST. 2013. The effect of Korean red ginseng on allergic inflammation in a murine model of allergic rhinitis. J. Ginseng Res. 37: 167-175.

20. Lee EJ, Song MJ, Kwon HS, Ji GE, Sung MK. 2012. Oral administration of fermented red ginseng suppressed ovalbumininduced allergic responses in female BALB/c mice. Phytomedicine 19: 896-903.

21. Ribeiro-Filho J, Leite FC, Costa HF, Calheiros AS, Torres RC, de Azevedo CT, et al. 2014. Curine inhibits mast celldependent responses in mice. J. Ethnopharmacol. 155: 11181124.

22. Park J, Seo JS, Kim SA, Shin S, Park JY, Han NS. 2017. Microbial diversity of commercial makgeolli and its influence on the organoleptic characteristics of Korean rice sourdough, jeung-pyun. J. Microbiol Biotechnol. 27: 1736-1743.

23. Suzuki K, Verma IM. 2008. Phosphorylation of SNAP-23 by ІкВ kinase 2 regulates mast cell degranulation. Cell 134: 485495.
24. Shim DW, Han JW, Sun X, Jang CH, Koppula S, Kim TJ, Kang TB, Lee KH. 2013. Lysimachia clethroides Duby extract attenuates inflammatory response in Raw 264.7 macrophages stimulated with lipopolysaccharide and in acute lung injury mouse model. J. Ethnopharmacol. 150: 10071015.

25. Bischoff SC. 2007. Role of mast cells in allergic and nonallergic immune responses: comparison of human and murine data. Nat. Rev. Immunol. 7: 93-104.

26. Lian Q, Cheng Y, Zhong C, Wang F. 2015. Inhibition of the IgE-mediated activation of RBL-2H3 cells by TIPP, a novel thymic immunosuppressive pentapeptide. Int. J. Mol. Sci. 16: $2252-2268$.

27. Choi P, Reiser H. 1998. IL-4: role in disease and regulation of production. Clin. Exp. Immunol. 113: 317-319.

28. Lee J. 2016. Regulation of IgE-mediated food allergy by IL-9 producing mucosal mast cells and type 2 innate lymphoid cells. Immune Netw. 16: 211-218.

29. Xiao S, Jiang J, Shim D, Kim T, Kang T, Lee K. 2014. Antiallergic effect of ethanolic extract of Flos Sophora japonica L. on Ca ionophore stimulated murine RBL-2H3 cells. J. Korean Soc. Food Sci. Nutr. 43: 349-354.

30. Burton OT, Oettgen HC. 2011. Beyond immediate hypersensitivity: evolving roles for IgE antibodies in immune homeostasis and allergic diseases. Immunol. Rev. 242: 128-143.

31. Tournier C, Dong C, Turner TK, Jones SN, Flavell RA, Davis RJ. 2001. MKK7 is an essential component of the JNK signal transduction pathway activated by proinflammatory cytokines. Genes Dev. 15: 1419-1426.

32. Zheng H, Jeong Y, Song J, Ji GE. 2011. Oral administration of ginsenoside Rh1 inhibits the development of atopic dermatitis-like skin lesions induced by oxazolone in hairless mice. Int. Immunopharmacol. 11: 511-518.

33. Li LC, Piao HM, Zheng MY, Lin ZH, Choi YH, Yan GH. 2015. Ginsenoside Rh2 attenuates allergic airway inflammation by modulating nuclear factor- $\mathrm{\kappa}$ activation in a murine model of asthma. Mol. Med. Rep. 12: 6946-6954.

34. Sun J, Song X, Hu S. 2008. Ginsenoside Rg1 and aluminum hydroxide synergistically promote immune responses to ovalbumin in BALB/c mice. Clin. Vaccine Immunol. 15: 303-307.

35. Lee IS, Uh I, Kim KS, Kim KH, Park J, Kim Y, et al. 2016. Anti-inflammatory effects of ginsenoside $\mathrm{Rg} 3$ via NF- $\mathrm{KB}$ pathway in A549 cells and human asthmatic lung tissue. J. Immunol. Res. 2016: 1-11.

36. Oh HA, Seo JY, Jeong HJ, Kim HM. 2013. Ginsenoside Rg1 inhibits the TSLP production in allergic rhinitis mice. Immunopharmacol. Immunotoxicol. 35: 678-686. 